\title{
Some cool considerations of external lumbar drainage during its widespread application in neurosurgical practice: a long way to go
}

\author{
Guichen $\mathrm{Li}^{1}$, Yang Zhang ${ }^{2}$, Jinchuan Zhao ${ }^{2}$, Zhiguo Han ${ }^{3}$, Xiaobo Zhu ${ }^{2^{*}}$ and Kun Hou${ }^{2^{*}}$
}

\begin{abstract}
External lumbar drainage (ELD) has gained wide popularity in neurosurgical practice since its' first introduction by $F$. Vourc'h in 1963. It manifests encouraging prospects in control of refractory intracranial hypertension, prevention of complications secondary to aneurysmal subarachnoid hemorrhage, prediction of shunt respondency in normal pressure hydrocephalus, management of cerebrospinal fluid (CSF) leakage, and application in bacterial meningitis and ventriculitis. But many questions on the efficacy and safety of ELD are remained to be answered by future studies. CSF overdrainage and ELD-related meningitis are the two most common and fatal complications due to inappropriate usage of ELD. Randomized controlled trials are badly in need to more safely and rationally guide the clinical application of ELD.
\end{abstract}

Keywords: Aneurysmal subarachnoid hemorrhage, Cerebrospinal fluid overdrainage, Complication, Meningitis, External lumbar drainage, Indication, Intracranial hypertension

\section{Background}

External drainage of cerebrospinal fluid (CSF) from the lumbar cistern via a plastic catheter was primarily described by F. Vourc'h in 1963 [1]. Since then, external lumbar drainage (ELD) of CSF has gained wide popularity in a variety of neurosurgical activities and procedures e.g. intraoperative cerebral relaxation, drainage of bloody or infectious CSF, control of refractory intracranial hypertension, preoperative evaluation of normal pressure hydrocephalus (NPH), prevention of complications secondary to aneurysmal subarachnoid hemorrhage (aSAH) [2-7]. However, just as each coin has its two sides, issues concerning the complications and unduly usage of ELD has also come [8-10]. In order to further explore the indications, contraindications, complications, recent developments and future considerations of ELD, we performed a comprehensive review of the related studies written in English on ELD in PubMed. And related articles in the reference lists of the identified studies were

\footnotetext{
*Correspondence: zhuxiaobo@126.com; hkyyayz@yeah.net

${ }^{2}$ Department of Neurosurgery, The First Hospital of Jilin University, 3302 Jilin

Road, Changchun 130031, China

Full list of author information is available at the end of the article
}

also reviewed. Furthermore, a search of ClinicalTrials.gov was also conducted for ongoing studies.

\section{Main indications \\ Controlling of intracranial hypertension}

Since the 1920s, when ELD had not been introduced, there were some reports of cerebral herniation secondary to lumbar puncture (LP) [11-13]. But most of the reports of cerebral herniation at that time were those patients harboring intracranial tumors. The forefather of modern neurosurgery Harvey Williams Cushing had ever advocated that lumbar drainage of CSF should be forbidden in patients with intracranial hypertension (ICH) for fear of cerebral herniation. And it has been and even still is treated as a solid doctrine by many neurosurgeons. Since the time when ELD was first introduced by F. Vourc'h [1], debates on its indications, complications, and contraindications have never ended. Many neurosurgeons still considered ELD a contraindication of ICH. Nevertheless, till in the 1990s, ELD was gradually and prudently used to control refractory ICH and encouraging results were observed [5, 14-21] (Table 1). In 1996 Brain Trauma Foundation recommended a two-tier 
Table 1 Some of the studies that focusing on control of refractory ICH with ELD

\begin{tabular}{|c|c|c|c|c|c|c|c|}
\hline \multirow[t]{2}{*}{ First author } & \multirow[t]{2}{*}{ Year } & \multirow[t]{2}{*}{ Type of study } & \multirow[t]{2}{*}{ No. of patients } & \multirow[t]{2}{*}{ Age group } & \multirow[t]{2}{*}{ Outcome } & \multicolumn{2}{|c|}{ Complications during EL } \\
\hline & & & & & & $\mathrm{CH}$ & Meningitis \\
\hline \multirow[t]{3}{*}{ Baldwin HZ [14] } & 1991 & & 5 & Children & Significant decrease in ICP (3) & 0 & 0 \\
\hline & & & & & Survived (3) & & \\
\hline & & & & & GOS $\geq 4(2)$ & & \\
\hline \multirow[t]{3}{*}{ Levy DI [15] } & 1995 & Retrospective & 16 & Children & Significant decrease in ICP (14) & 0 & 0 \\
\hline & & & & & Survived (14) & & \\
\hline & & & & & GOS $\geq 4(11)$ & & \\
\hline \multirow[t]{3}{*}{ Willemse RB [16] } & 1998 & Retrospective & 7 & Adults & Significant decrease in ICP (NA) & 0 & 0 \\
\hline & & & & & Survived (5) & & \\
\hline & & & & & GOS $\geq 4$ (3) & & \\
\hline \multirow[t]{3}{*}{ Münch EC [17] } & 2001 & Prospective & 23 & Adults & Significant decrease in ICP (23) & 2 & 0 \\
\hline & & & & & Survived (15) & & \\
\hline & & & & & $\mathrm{GOS} \geq 4(10)$ & & \\
\hline \multirow[t]{3}{*}{ Murad A (18) } & 2008 & Prospective & 8 & Adults & Significant decrease in ICP (8) & 0 & 0 \\
\hline & & & & & Survived (NA) & & \\
\hline & & & & & $\mathrm{GOS} \geq 4(\mathrm{NA})$ & & \\
\hline \multirow[t]{3}{*}{ Tuettenberg J [5] } & 2009 & Prospective & 100 & Children and adults & Significant decrease in ICP (NA) & 12 & 7 \\
\hline & & & & & Survived (55) & & \\
\hline & & & & & GOS $\geq 4(36)$ & & \\
\hline \multirow[t]{3}{*}{ Llompart-Pou JA [19] } & 2011 & Retrospective & 30 & Adults & Significant decrease in ICP (NA) & 0 & 1 \\
\hline & & & & & Survived (23) & & \\
\hline & & & & & GOS $\geq 4(18)$ & & \\
\hline \multirow[t]{3}{*}{ Murad A [20] } & 2011 & Prospective & 6 & Adults & Significant decrease in ICP (NA) & 0 & 0 \\
\hline & & & & & Survived (4) & & \\
\hline & & & & & GOS $\geq 4(N A)$ & & \\
\hline \multirow[t]{3}{*}{ Murad A [21] } & 2012 & Prospective & 15 & Adults & Significant decrease in ICP (NA) & 1 & 0 \\
\hline & & & & & Survived (12) & & \\
\hline & & & & & $\mathrm{GOS} \geq 4(\mathrm{NA})$ & & \\
\hline
\end{tabular}

NA not applicable, GOS Glasgow Outcome Scale, ICP intracranial pressure, $C H$ cerebral herniation

strategy for the management of patients with $\mathrm{ICH}$, which was treated as a standard protocol for control of intracranial pressure (ICP) in many centers [20-22]. This strategy is not only used in patients with traumatic brain injuries (TBI) but also in patients with other intracranial diseases. The first-tier measures include osmotic solutions, ventricular drainage of CSF, moderate hyperventilation and the second-tier include decompressive craniectomy, barbiturate coma or therapeutic hypothermia. But there were usually some cases in which the two-tier strategy was ineffective or inappropriate. Emerging evidences have demonstrated that application of ELD leads to a significant decrease in ICP and an increase in cerebral perfusion pressure (CPP) [5, 21]. CPP and ICP have been demonstrated to independently affect outcome in patients with severe brain injury [5,23-26]. As was worried by some neurosurgeons, cerebral herniation did happen in patients with $\mathrm{ICH}$ after the application of ELD. The reported incidence of cerebral herniation ranged from 0 to $12 \%$ (Table 1). But just as Tuettenberg J and colleagues stated temporary clinical signs of cerebral herniation do not lead to lower rates of neurological recovery or a higher mortality rate [5].

However, the published studies on control of $\mathrm{ICH}$ with ELD merely include a relative small number of patients and no prospective randomized controlled trial (RCT) has ever been published till now. As was pointed by Tuettenberg J et al. that ELD of CSF in patients with intracranial hypertension leads to a significant and clinically relevant reduction in ICP, however, it remains unclear whether drainage of CSF improves clinical outcome by reducing ICP [5]. This calls for future RCTs. 


\section{Aneurysmal subarachnoid hemorrhage}

Aneurysmal subarachnoid hemorrhage manifests a challenge to the public health not only for the risk of fatal aneurysmal rebleeding but also for the high morbidity of cerebral vasospasm (CVS), ICH and shunt-dependent hydrocephalus. CVS and $\mathrm{ICH}$ are two of the most common complications of aSAH. They might occur independently or reciprocally. Although treatments targeting at the prevention of CVS as $3-\mathrm{H}$ therapy, calcium-channel blocker, arterial papaverine infusion, and angioplasty have been applied in the past decades, symptomatic CVS, of which the incidence could be as high as $40 \%$, is still the main indicator of unfavorable outcomes [27, 28]. The occurrence of CVS involves many pathophysiological processes, but there is no doubt that subarachnoid blood and its degradation products contribute mostly. Some Japanese authors have been using CSF drainage in aSAH patients since the early 1980s, but with conflicting results $[29,30]$. Klimo P Jr and colleagues showed a marked reduction in symptomatic CVS, vasospasm-induced stroke and the need for endovascular procedures after 9 years utility of ELD [28]. They hypothesized that lumbar CSF drainage is superior to drainage from the lateral ventricles or intracranial cisterns. They believed that drainage of CSF from the lumbar cistern would promote circulation of newly produced CSF and blood cells from the ventricles through the subarachnoid space, whereas CSF drainage directly from the lateral ventricles may contribute to stasis of blood cells within the subarachnoid cistern and hence actually add to the risk of vasospasm. This might help explain the conflicting results with different drainage modalities. Since then, many reports with promising results were published in the prevention of CVS with ELD after aSAH [31,32]. The most important one among them is the LUMAS trial. This RCT recruited 210 patients with aSAH, and demonstrated that ELD of CSF after aSAH reduces the prevalence of delayed ischemic neurological deficit and improves early clinical outcome but fails to improve outcome at 6 months after aSAH.

$\mathrm{ICH}$ is a common complication of aSAH, it may be secondary to and exacerbate CVS. To our knowledge, there is still no specific guideline or recommendation for the control of ICH after aSAH. Most institutions follow the two-tier guideline of Brain Trauma Foundation for control ICP in aSAH patients [5, 20-22]. But there are two issues before the implementation of the two-tier therapy: a) aSAH presents challenges which require special therapeutic considerations for management of ICP especially in the setting of vasospasm; b) there would always be some cases with refractory $\mathrm{ICH}$ that could not be controlled with this guideline.
Osmotic solution as mannitol or diuretic as furosemide would decrease intravascular fluid volume. Sedation and barbiturate coma carry the risk of hypotension. Considering the side effects of hypovolemia and hypotension, which are inconsistent with the $3-\mathrm{H}$ therapy of aSAH, the two-tier guideline is not always suitable for ICP control in aSAH patients [20, 21]. Even the two-tier therapy is initiated consecutively there still would be some refractory cases in whom ICP could not be satisfactorily controlled [5]. However, some reports have demonstrated encouraging results of ICP control with the utility of ELD in aSAH patients $[5,20,21]$. The one that should be pointed out was conducted by Tuettenberg and colleagues [5]. This prospective study included 100 patients ( 45 with TBI, 55 with aSAH) and followed a stepwise design according to the two-tier therapy before ELD. When the two-tier therapy was ineffective, ELD was initiated. It demonstrated a significant and long-lasting reduction in ICP and an increase in CPP after application of ELD but failed to prove that ELD could improve clinical outcome by reducing ICP. However, large-scale RCT is anticipated in the future to strongly verify the effectiveness and safety of ELD in controlling of ICH in aSAH patients.

\section{Predictive value in normal pressure hydrocephalus}

The term normal pressure hydrocephalus (NPH) was first described by Hakim and Adams in 1965, which consisted of a triad of clinical symptoms including gait disturbance, dementia, and urinary incontinence in patients with enlarged ventricles and normal intracranial pressure [33]. It was subsequently divided into two subtypes: idiopathic (primary) $\mathrm{NPH}$ and secondary NPH. Although permanent shunting is currently the most effective treatment modality, experience in the past decades indicated that the rate of postsurgical complications including death and severe residual morbidity could be as high as $30-40 \%[6,34,35]$. So an effective method that could accurately predict the respondency to shunting is of great importance. Historically, additional tests as isotope cisternography, measurement of CSF outflow resistance and repeated LP were developed to screen the potential responders to shunting but with limited efficacy [36-38]. However, an ELD for a period of 3-5 days is gaining acceptance as a more sensitive predictor for patients who might respond well to shunting $[6,38,39]$. Published studies demonstrated that the accuracy of prediction could be greater than $90 \%[6,38]$. The question is although the predictive value of a positive ELD was high, that of a negative ELD was deceptively low because of the high rate of false negative results $[6,38,39]$. Thus patients with a positive ELD are sure the most appropriate candidates for permanent shunt placement, whereas, those with a negative ELD test should be advised for further investigation of additional tests $[6,39]$. By the way, no RCT on this specific topic was available till now. 


\section{Management of CSF leakage}

CSF leakage is commonly encountered in the circumstances of head trauma and iatrogenic injuries. Although most of the cases with CSF leakage resolved spontaneously within 24-48 h, delayed diagnosis and management may lead to life-threatening conditions [40]. Historically, the management of CSF leakage consisted of noninvasive (conservative) and invasive (surgical) therapies. Because of its nature of self-limitedness, CSF leakage can spontaneously resolve with merely conservative managements including bedrest, head elevation, prophylactic antibiotics and strict sinus precautions (e.g. avoiding nasal blowing or Valsalva maneuver) in a significant proportion of patients. Those patients without spontaneous resolution in a certain period of time were previously thought of definite candidates for surgical intervention by some authors [41]. However, the publication of many studies indicated that ELD could be considered a good option in whom spontaneous resolution of CSF leakage was not achieved before surgical intervention was initiated [40-43]. But there are still some questions that need to be raised before the extensive application of ELD: a) When ELD should be considered after the occurrence of CSF leakage? b) How long is most appropriate with respect to the duration of ELD? c) When ELD should be stopped if the resolution of CSF leakage was not achieved? In view of the fact that no RCT on this issue has ever been published, we should be cautious when considering ELD before the questions aforementioned are satisfactorily answered.

\section{Intraoperative brain relaxation}

It is well-known that a perfect intracranial surgery depends not only on the neurosurgeon's excellent skills but also adequate intraoperative brain relaxation (IOBR). Because satisfactory brain relaxation results in easier access to the target lesion and reduces iatrogenic injuries due to intraoperative retraction. Strategies that aim to get favorable IOBR include hyperventilation, CSF drainage and usage of hyperosmotic agents during neurosurgery, among which mannitol is considered as the standard and a first-choice hyperosmotic agent [44]. The principle mechanism of hyperosmotic agents in brain relaxation is the induction of water shift from brain tissues to intravascular space and the subsequent brain-bulk reduction. However, administration of mannitol can be associated with severe adverse effects such as hypovolemia, rebound ICP elevation, hyperkalemia and renal failure $[45,46]$. Currently, hypertonic saline as a seemingly more promising hyperosmotic agent has gained renewed interest in the field of IOBR [44, 47]. But hypertonic saline increases serum sodium concentration greatly. Intraoperative ELD, which relaxes brain by draining out certain amount of CSF, has been successfully applied in numerous intracranial surgeries [2, 48-50]. It is a safe and effective method for intraoperative brain relaxation and does not interfere with circulating blood volume and hydroelectrolytic equilibration. However, the application of ELD is not without complications. Intracranial hemorrhage and acute cerebellar tonsilar herniation were frequently reported after the introduction of ELD especially in patients with asymptomatic Chiari I malformation $[9,51,52]$. So it's true that ELD is an efficient modality in IOBR, whereas should be used prudently. Perhaps due to the difference in mechanism of brain relaxation, no study on comparing the efficacy of hyperosmotic agents and ELD in IOBR has ever been conducted.

\section{Application in bacterial meningitis and ventriculitis}

It is well known that bacterial meningitis and/or ventriculitis $(\mathrm{BM} / \mathrm{V})$ is an unavoidable complication of ELD. But more encouraging outcome has also been obtained by the use of ELD in pediatric and adult patients with BM/V compared with the traditional therapies [53-55]. With the accumulation of evidences that LP should not always be considered a contraindication in acute severe $\mathrm{BM} / \mathrm{V}$ for fear of cerebral herniation [56], the application of ELD is warranted. But LP or ELD should be considered contraindication when the following situations were met: a) Signs of a cerebral mass lesion; b) Ongoing or impending cerebral herniation; c) Ongoing epileptic seizures; d) Papilledema; e) Severe coagulopathy; f) Infection at the site of LP [56]. The main pathophysiological mechanism by which ELD exerts its effectiveness might be control of $\mathrm{ICH}$ and drainage of cytotoxins in the CSF $[53,55]$. But as a result of the limited literature on this issue, studies with larger number of patients and RCT design are anticipated in the future. And by the completion of this manuscript no study comparing the efficacy of ELD and repeated LP in $\mathrm{BM} / \mathrm{V}$ has ever been published.

\section{Complications of ELD}

Although ELD is an effective and safe treatment modality which has been successfully utilized in a variety of neurosurgical procedures, it is not risk free. Complications even some fatal complications secondary to inappropriate usage of ELD were frequently reported. In general, these complications can be divided into three categories according to Acikbas: A) complications related to alterations in CSF drainage rate, B) complications due to mechanical failure of the catheter, and $C$ ) infections [57]. As complications related to CSF drainage rate and infections are preventable and modifiable, they are the main points of our discussion.

\section{CSF overdrainage}

CSF overdrainage is perhaps the most common complication of ELD, the incidence of which can be as high as $63 \%$ $[58,59]$. It might alternatively be expressed as intracranial 
hypotension, brain sag, sinking brain syndrome, sinking skin flap syndrome or CSF hypovolemia according to different reports and personal preference [51, 52, 59, 60]. And the clinical presentations of CSF overdrainage range from mere headache, cranial nerve palsy, mental state alteration, pneumocephalus, and intracranial hemorrhage to death $[8,9,51,52,57,59-61]$. The commonly accepted mechanism of CSF overdrainage is downward displacement of intracranial contents due to the pressure gradient between the intracranial and intrathecal compartments [8, 51, 59, 61]. Although identification of brain sagging, venous engorgement, dura enhancement, pituitary enhancement and subdural fluid collection on MRI is superior $[8,59,61,62]$, emergent CT combined with clinical presentation may be more convenient and practical in reaching the diagnosis of CSF overdrainage in daily practice $[52,60]$. The most commonly reported findings on head CT include effacement of the basal cisterns, ventricular collapse, diffuse edema, pneumocephalus and subdural fluid collection [59, 60]. A simple and practical assembly of diagnosis criteria used by Komotar RJ and colleagues includes clinical signs of transtentorial herniation, head CT scans revealing effacement of the basal cisterns with an oblong brainstem, and improvement of symptoms after placement of the patient in the Trendelenburg position $\left(-15\right.$ to $\left.-30^{\circ}\right)$ [63].

Though the term CSF overdrainage indicates excessive drainage of CSF, there is still no definite upper limit concerning the volume drained out in a certain period of time at present. The targeted volume ranges from 5 to $20 \mathrm{ml}$ per hour according to different reports [52, 57-61], which is no more than the CSF production rate in an adult (roughly $20 \mathrm{ml} / \mathrm{h}$ ). Though in our past study, we have found that the mean daily CSF volume drained out was statistically associated with the incidence of CSF overdrainage [52], we could also see the occurence of CSF overdrainage even only a smaller amount of CSF was drained out. So, perhaps the optimum drainage volume per unit of time does not ever exsit. The most reliable way to avoid overdrainage might be based on vigilant observation and timely radiological findings. When overdrainage happens, the most appropriate and efficient managements are temporary catheter clipping, Trendelenburg position and intravenous hydration.

\section{ELD-related meningitis}

Meningitis is a common and inevitable complication of ELD. The incidence varies among different reports, which could be higher than $40 \%[10,19,57,64-67]$ (Table 2). Although a myriad of reasons, such as primary diseases, drain indwelling procedures, patient population, and use of prophylactic antibiotics, could help explain the large variation in infection rates in different reports, a clear
Table 2 Studies with identified infected patients after ELD

\begin{tabular}{llll}
\hline First author & Year & No. of patients & Infected (percentage) \\
\hline Coplin WM [67] & 1999 & 312 & $13(4.2 \%)$ \\
Açikbaş SC [57] & 2002 & 63 & $5(7.9 \%)$ \\
Schade RP [66] & 2005 & 125 & $8(6.4 \%)$ \\
Scheithauer S [10] & 2010 & 79 & $17(21.5 \%)$ \\
Leverstein-van Hall & 2010 & 216 & $14(6.5 \%)$ \\
MA [65] & & & $1(3 \%)$ \\
Llompart-Pou JA [19] & 2011 & 30 & $42(44.7 \%)$ \\
Chen C [64] & 2014 & 94 &
\end{tabular}

Table 3 Studies with identified pathogens secondary to ELD

\begin{tabular}{|c|c|c|c|}
\hline First author & Year & $\begin{array}{l}\text { No. of Infected } \\
\text { patiens }\end{array}$ & Pathogen \\
\hline \multirow[t]{8}{*}{ Coplin WM [67] } & 1999 & 13 & CNS (5) \\
\hline & & & $S$ aureus (2) \\
\hline & & & $\begin{array}{l}\text { CNS, Corynebacterium } \\
\text { Species (1) }\end{array}$ \\
\hline & & & K pneumonia(1) \\
\hline & & & $\begin{array}{l}\text { Actinobacter } \\
\text { calcoaceticus (1) }\end{array}$ \\
\hline & & & Enterobacter cloacae (1) \\
\hline & & & $P$ aeruginosa (1) \\
\hline & & & Group A Streptococcus (1) \\
\hline \multirow[t]{4}{*}{ Açikbaş SC [57] } & 2002 & 5 & S aureus (2) \\
\hline & & & CNS (1) \\
\hline & & & Acinetobacter SPP (1) \\
\hline & & & Enterobacter SPP (1) \\
\hline \multirow[t]{6}{*}{ Schade RP [66] } & 2005 & 8 & S aureus (3) \\
\hline & & & CNS (1) \\
\hline & & & Escherichia coli (1) \\
\hline & & & $P$ aeruginosa (1) \\
\hline & & & Enterococcus faecalis (1) \\
\hline & & & Proteus mirabilis (1) \\
\hline \multirow[t]{2}{*}{ Scheithauer S [69] } & 2009 & 20 & CNS (16) \\
\hline & & & $S$ aureus (4) \\
\hline \multirow[t]{5}{*}{ Hetem DJ [68] } & 2010 & 72 & CNS (33) \\
\hline & & & S aureus (17) \\
\hline & & & Gram-negative bacteria (11) \\
\hline & & & $\begin{array}{l}\text { Other Gram-positive } \\
\text { bacteria (11) }\end{array}$ \\
\hline & & & $\begin{array}{l}\text { Multiple microorganisms } \\
\text { cultured (14) }\end{array}$ \\
\hline $\begin{array}{l}\text { Llompart-Pou } \\
\text { JA (19) }\end{array}$ & 2011 & 1 & CNS (1) \\
\hline
\end{tabular}


definition of drainage-related infection might be the most urgent issue that should be answered by the future studies and guidelines [66, 68-70]. Generally speaking, the diagnosis of meningitis consists of the following points: a) no previous meningitis before lumbar drain insertion; b) sterile CSF culture at the time of lumbar drain insertion; c) continuous lumbar drainage $>24 \mathrm{~h}$ before the positive culture was aspirated; and d) positive culture of a CSF specimen collected from the lumbar drain or from a lumbar puncture; e) clinical symptoms as fever, nuchal rigidity, and mental alteration that could not be explained by other causes $[10,65,67,68]$. Alterations of leukocyte count, protein concentration and glucose concentration in routine CSF tests are supportive proofs of meningitis but with limited predictive or diagnostic value [67, 71]. Positive CSF-drain cultures are strongly associated with development of ELD-related meningitis [68]. At present, literatures solely focusing on the incidence, risk factors and preventive solutions of ELD-related meningitis are scarce $[57,67]$. Most of the related articles are a mixture of ELD and external ventricular drainage (EVD) $[10,65,66,68,69]$. Because procedure complexity, drainage duration, and distance to the brain are all potential risks for intracranial infection, ELD-related meningitis should be treated as a unique entity from its EVD-related counterpart and be studied separately.

In patients with ELD-related meningitis, the responsible pathogens are diverse. But coagulase-negative staphylococci and staphylococcus aureus are the commonest causative organisms $[19,57,66-69]$ (Table 3). Single organism infections are far more than those with multiple organisms (Table 2). Site leakage, drain blockage, frequency of CSF sampling, number of CSF sampling sites are all reported risk factors for ELD-related meningitis, but the most important one may be the duration of catheterization [64-66]. Prophylactic antibiotics usage is controversal for prevention of drain associated infection [65-67]. A prospective study conducted by Leverstein-van Hall MA and colleagues indicates that a multidisciplinary approach, in which different preventive measures were combined, was associated with a significant reduction in incidence of drain-related meningitis [65].

In general, ELD-related meningitis is a complex entity, of which a lot of questions are with no satisfactory answers. As Kasper EM proposed, a number of points need to be raised when going ahead into further studies: a) What is the correlation of concurrent infections from indwelling catheters and possible concurrent systemic infections (fever?)? b) What is the accuracy of CSF test result? C) Is there a temporal correlation between length of device use and risk of infection? d) Is there a risk from routine CSF sampling to carry an infection into a closed drainage system? e) Drainage placement techniques and protocols need to be addressed (eg, the distance to drain exit site as well as a rationale for (not) using antibiotics) [70]. By the way, till the completion of this manuscript, no RCT has ever been reported concerning the topic of ELDrelated meningitis.

\section{Ongoing clinical trials and future considerations}

A ClinicalTrials.gov search of ongoing clinical trials concerning the application of ELD in neurosurgical practice was performed on Jan 9th, 2015. In all, 5 ongoing studies were identified, with 2 on aSAH, 2 on acute spinal cord injury, and the last one on intraventricular hemorrhage

Table 4 Ongoing studies concerning the application of ELD

\begin{tabular}{|c|c|c|c|c|}
\hline Sponsor & Start Date & Design & Brief title & Aim \\
\hline $\begin{array}{l}\text { Charite University, Berlin, } \\
\text { Germany }\end{array}$ & $\begin{array}{l}\text { December } \\
2010\end{array}$ & $\begin{array}{l}\text { Single blind, } \\
\text { Randomized }\end{array}$ & $\begin{array}{l}\text { EARLYdrain - Outcome After Early } \\
\text { Lumbar CSF-drainage in Aneurysmal } \\
\text { SAH }\end{array}$ & $\begin{array}{l}\text { To investigate whether drainage of cerebral } \\
\text { spinal fluid via a lumbar route will improve } \\
\text { outcome after intracranial SAH }\end{array}$ \\
\hline $\begin{array}{l}\text { University of } \\
\text { Erlangen-Nürnberg } \\
\text { Medical School }\end{array}$ & June 2010 & $\begin{array}{l}\text { Open label, } \\
\text { Randomized }\end{array}$ & $\begin{array}{l}\text { A Randomised Controlled Trial of } \\
\text { Lumbar Drainage to Treat } \\
\text { Communicating Hydrocephalus } \\
\text { After Severe Intraventricular } \\
\text { Hemorrhage }\end{array}$ & $\begin{array}{l}\text { To determine if usage of early lumbar drainage } \\
\text { leads to less shunt surgery and less catheter } \\
\text { associated complications in patients with } \\
\text { communicating hydrocephalus after intracerebral } \\
\text { hemorrhage with severe ventricular involvement }\end{array}$ \\
\hline $\begin{array}{l}\text { Odense University } \\
\text { Hospital }\end{array}$ & $\begin{array}{l}\text { August } \\
2013\end{array}$ & $\begin{array}{l}\text { Open label, } \\
\text { Randomized }\end{array}$ & $\begin{array}{l}\text { Use of Lumbar Drain to Remove } \\
\text { Clots in Patients Admitted to the } \\
\text { Neuro-ICU After Subarachnoid } \\
\text { Hemorrhage }\end{array}$ & $\begin{array}{l}\text { To test if CSF obtained from ELD has a higher } \\
\text { concentration of blood than CSF from external } \\
\text { ventricular drain in patients suffering from SAH }\end{array}$ \\
\hline $\begin{array}{l}\text { University of British } \\
\text { Columbia }\end{array}$ & March 2008 & $\begin{array}{l}\text { Single blind, } \\
\text { Non-Randomized }\end{array}$ & $\begin{array}{l}\text { Cerebrospinal Fluid (CSF) Drainage } \\
\text { and Cytokine Profiling in the Treatment } \\
\text { of Acute Spinal Cord Injury (SCI) }\end{array}$ & $\begin{array}{l}\text { To evaluate CSF drainage as a potential } \\
\text { neuroprotective strategy after acute spinal } \\
\text { cord injury }\end{array}$ \\
\hline $\begin{array}{l}\text { St. Joseph's Hospital and } \\
\text { Medical Center, Phoenix }\end{array}$ & $\begin{array}{l}\text { October 2, } \\
2015\end{array}$ & $\begin{array}{l}\text { Open label, } \\
\text { Randomized }\end{array}$ & $\begin{array}{l}\text { Cerebrospinal Fluid Drainage (CSFD) } \\
\text { in Acute Spinal Cord Injury }\end{array}$ & $\begin{array}{l}\text { To evaluate the safety and efficacy of CSFD } \\
\text { and to provide a preliminary clinical efficacy } \\
\text { evaluation of the combination of CSFD and } \\
\text { elevation of mean arterial pressure in patients } \\
\text { with acute spinal cord injury }\end{array}$ \\
\hline
\end{tabular}


(Table 4). Four of the 5 ongoing studies were designed in a randomized manner, while 1 was non-randomized. From the ongoing clinical trials and the published studies we could notice that clinical studies of high evidence level on the issue of ELD are few. In order to more safely and rationally apply ELD in neurosurgical practice, a lot of RCTs are needed in future investigations.

\section{Conclusions}

ELD is a useful and promising modality which has gained wide popularity in a variety of neurosurgical practices. Although, encouraging outcomes have been obtained in control of $\mathrm{ICH}$, prediction of shunt respondence in $\mathrm{NPH}$, management of CSF leakage and bacterial meningitis and ventriculitis, intraoperative relaxation, and so on, fatal complications as severe CSF overdrainage and ELDrelated meningitis are urgent issues that need to be addressed in future studies. RCTs are badly in need to more safely and rationally guide the clinical application of ELD.

\section{Competing interests}

The authors declare that they have no competing interests.

\section{Authors' contributions}

$\mathrm{GL}$ and $\mathrm{KH}$ carried out the studies, participated in collecting data, and drafted the manuscript. $Y Z, J Z$ and $Z H$ revised the manuscript critically for important intellectual content. XZ helped to draft the manuscript and gave final approval of the version to be published. All authors read and approved the final manuscript.

\section{Acknowledgement}

None

\section{Author details}

'Department of Neurology, The First Hospital of Jilin University, Changchun, China. ${ }^{2}$ Department of Neurosurgery, The First Hospital of Jilin University, 3302 Jilin Road, Changchun 130031, China. ${ }^{3}$ Department of Surgery, Changchun Orthopaedics Hospital, Changchun, China.

Received: 10 December 2015 Accepted: 3 May 2016

Published online: 18 May 2016

\section{References}

1. Vourc'H G. Continuous cerebrospinal fluid drainage by indwelling spinal catheter. Br J Anaesth. 1963;35:118-20

2. Viswanathan $A$, Whitehead WE, Luerssen $T G$, Jea $A$. Use of lumbar drainage of cerebrospinal fluid for brain relaxation in occipital lobe approaches in children: technical note. Surg Neurol. 2009;71(6):681-4.

3. Huttner HB, Nagel S, Tognoni E, Köhrmann M, Jüttler E, Orakcioglu B, et al, Intracerebral hemorrhage with severe ventricular involvement: lumbar drainage for communicating hydrocephalus. Stroke. 2007;38(1):183-7.

4. Remeš F, Tomáš $R$, Jindrák V, Vaniš V, Setlík M. Intraventricular and lumbar intrathecal administration of antibiotics in postneurosurgical patients with meningitis and/or ventriculitis in a serious clinical state. J Neurosurg. 2013; 119(6):1596-602

5. Tuettenberg J, Czabanka M, Horn P, Woitzik J, Barth M, Thomé C, et al. Clinical evaluation of the safety and efficacy of lumbar cerebrospinal fluid drainage for the treatment of refractory increased intracranial pressure. J Neurosurg. 2009;110(6):1200-8.

6. Panagiotopoulos $\vee$, Konstantinou D, Kalogeropoulos A, Maraziotis T. The predictive value of external continuous lumbar drainage, with cerebrospinal fluid outflow controlled by medium pressure valve, in normal pressure hydrocephalus. Acta Neurochir (Wien). 2005;147(9):953-8.

7. Aydin HE, Ozbek Z, Aydin N, Bolluk O, Vural M, Arslantas A, Atasoy MA Application of lumbar drainage in vasospasm after spontaneous subarachnoid hemorrhage and prevention of late cerebral infarction. Acta Neurochir Suppl. 2015;120:255-8.

8. Dagnew $\mathrm{E}$, van Loveren HR, Tew Jr JM. Acute foramen magnum syndrome caused by an acquired Chiari malformation after lumbar drainage of cerebrospinal fluid: report of three cases. Neurosurgery. 2002;51(3):823-8.

9. Yuan $X$, Zhao H, Zhao C, Zhao H, Xiao H, Sun G, et al. Duret hemorrhage after lumbar drainage. J Craniofac Surg. 2014;25(4):1551-2.

10. Scheithauer S, Bürgel U, Bickenbach J, Häfner H, Haase G, Waitschies B, et al. External ventricular and lumbar drainage-associated meningoventriculitis: prospective analysis of time-dependent infection rates and risk factor analysis. Infection. 2010;38(3):205-9.

11. Hepburn H. The risk of spinal puncture. Can Med Assoc J. 1938;39:449-50.

12. Masson C. The dangers of diagnostic lumbar puncture in increased intracranial pressure due to brain tumor, with a review of 200 cases in which lumbar puncture was done. Res Nerv Ment Dis Proc. 1927:8:422.

13. Nash C. Cerebellar herniation as a cause of death. Ann Otol Rhinol Laryngol. 1937;46:673-80.

14. Baldwin HZ, Rekate HL. Preliminary experience with controlled external lumbar drainage in diffuse pediatric head injury. Pediatr Neurosurg. 1991;17:115-20.

15. Levy DI, Rekate HL, Cherny WB, Manwaring K, Moss SD, Baldwin HZ. Controlled lumbar drainage in pediatric head injury. J Neurosurg. 1995:83:453-60.

16. Willemse RB, Egeler-Peerdeman SM. External lumbar drainage in uncontrollable intracranial pressure in adults with severe head injury: a report of 7 cases. Acta Neurochir Suppl. 1998;71:37-9.

17. Münch EC, Bauhuf C, Horn P, Roth HR, Schmiedek P, Vajkoczy P. Therapy of malignant intracranial hypertension by controlled lumbar cerebrospinal fluid drainage. Crit Care Med. 2001;29(5):976-81.

18. Murad A, Ghostine S, Colohan ART. Controlled lumbar drainage in medically refractory increased intracranial pressure. A safe and effective treatment. Acta Neurochir Suppl. 2008;102:89-91.

19. Llompart-Pou JA, Abadal JM, Pérez-Bárcena J, Molina M, Brell M, Ibáñez J, et al. Long-term follow-up of patients with post-traumatic refractory high intracranial pressure treated with lumbar drainage. Anaesth Intensive Care. 2011:39(1):79-83.

20. Murad A, Ghostine S, Colohan AR. Role of controlled lumbar CSF drainage for ICP control in aneurysmal SAH. Acta Neurochir Suppl. 2011;110(Pt 2):183-7.

21. Murad A, Ghostine S, Colohan AR. A case for further investigating the use of controlled lumbar cerebrospinal fluid drainage for the control of intracranial pressure. World Neurosurg. 2012;77(1):160-5.

22. Bullock R, Chesnut RM, Clifton G, Ghajar J, Marion DW, Narayan RK, et al. Guidelines for the management of severe head injury. Brain Trauma Foundation, American Association of Neurological Surgeons, Joint Section on Neurotrauma and Critical Care. J Neurotrauma. 1996;13(11):641-734.

23. Balestreri M, Czosnyka M, Hutchinson P, Steiner LA, Hiler M, Smielewski P, et al. Impact of intracranial pressure and cerebral perfusion pressure on severe disability and mortality after head injury. Neurocrit Care. 2006:4(1):8-13.

24. Marmarou A, Saad A, Aygok G, Rigsbee M. Contribution of raised ICP and hypotension to CPP reduction in severe brain injury: correlation to outcome. Acta Neurochir Suppl. 2005;95:277-80

25. Kirkness CJ, Burr RL, Cain KC, Newell DW, Mitchell PH. Relationship of cerebral perfusion pressure levels to outcome in traumatic brain injury. Acta Neurochir Suppl. 2005;95:13-6.

26. Juul N, Morris GF, Marshall SB, Marshall LF. Intracranial hypertension and cerebral perfusion pressure: influence on neurological deterioration and outcome in severe head injury. The Executive Committee of the International Selfotel Trial. J Neurosurg. 2000;92(1):1-6.

27. Corsten L, Raja A, Guppy K, Roitberg B, Misra M, Alp MS, et al. Contemporary management of subarachnoid hemorrhage and vasospasm: the UIC experience. Surg Neurol. 2001;56(3):140-8.

28. Klimo Jr P, Kestle JR, MacDonaELD JD, Schmidt RH. Marked reduction of cerebral vasospasm with lumbar drainage of cerebrospinal fluid after subarachnoid hemorrhage. J Neurosurg. 2004;100(2):215-24.

29. Kawakami $Y$, Shimamura $Y$. Cisternal drainage after early operation of ruptured intracranial aneurysm. Neurosurgery. 1987;20(1):8-14.

30. Kasuya $H$, Shimizu T, Kagawa M. The effect of continuous drainage of cerebrospinal fluid in patients with subarachnoid hemorrhage: a retrospective analysis of 108 patients. Neurosurgery. 1991;28(1):56-9.

31. Kwon OY, Kim YJ, Kim YJ, Cho CS, Lee SK, Cho MK. The utility and benefits of external lumbar CSF drainage after endovascular coiling on aneurysmal subarachnoid hemorrhage. J Korean Neurosurg Soc. 2008;43(6):281-7.

32. Al-Tamimi $Y Z$, Bhargava D, Feltbower RG, Hall G, Goddard AJ, Quinn AC, et al. Lumbar drainage of cerebrospinal fluid after aneurysmal subarachnoid 
hemorrhage: a prospective, randomized, controlled trial (LUMAS). Stroke. 2012;43(3):677-82.

33. Hakim S, Adams RD. The special clinical problem of symptomatic hydrocephalus with normal cerebrospinal fluid pressure. Observations on cerebrospinal fluid hydrodynamics. J Neurol Sci. 1965;2(4):307-27.

34. Graff-Radford NR, Godersky JC. Normal-pressure hydrocephalus. Onset of gait abnormality before dementia predicts good surgical outcome. Arch Neurol. 1986;43:940-2.

35. Vanneste J, Augustijn P, Dirven C, Tan WF, Goedhart ZD. Shunting normalpressure hydrocephalus: do the benefits outweigh the risks? A multicenter study and literature review. Neurology. 1992;42(1):54-9.

36. Governale LS, Fein N, Logsdon J, Black PM. Techniques and complications of external lumbar drainage for normal pressure hydrocephalus. Neurosurgery. 2008:63(4 Suppl 2):379-84.

37. Wikkelsø C, Andersson H, Blomstrand C, Lindqvist G. The clinical effect of lumbar puncture in normal pressure hydrocephalus. J Neurol Neurosurg Psychiatry. 1982;45(1):64-9.

38. Marmarou A, Young HF, Aygok GA, Sawauchi S, Tsuji O, Yamamoto T, et al. Diagnosis and management of idiopathic normal-pressure hydrocephalus: a prospective study in 151 patients. J Neurosurg. 2005;102(6):987-97.

39. Shprecher D, Schwalb J, Kurlan R. Normal pressure hydrocephalus: diagnosis and treatment. Curr Neurol Neurosci Rep. 2008;8(5):371-6.

40. Dalgic A, Okay HO, Gezici AR, Daglioglu E, Akdag R, Ergungor MF. An effective and less invasive treatment of post-traumatic cerebrospinal fluid fistula: closed lumbar drainage system. Minim Invasive Neurosurg. 2008:51(3):154-7.

41. Friedman JA, Ebersold MJ, Quast LM. Persistent posttraumatic cerebrospinal fluid leakage. Neurosurg Focus. 2000;9(1):e1.

42. Allen KP, Isaacson B, Purcell P, Kutz Jr JW, Roland PS. Lumbar subarachnoid drainage in cerebrospinal fluid leaks after lateral skull base surgery. Otol Neurotol. 2011;32(9):1522-4.

43. Bell RB, Dierks EJ, Homer L, Potter BE. Management of cerebrospinal fluid leak associated with craniomaxillofacial trauma. J Oral Maxillofac Surg. 2004; 62(6):676-84.

44. Shao L, Hong F, Zou Y, Hao X, Hou H, Tian M. Hypertonic saline for brain relaxation and intracranial pressure in patients undergoing neurosurgical procedures: a meta-analysis of randomized controlled trials. PLoS One. 2015; 10(1):e0117314.

45. Himmelseher S. Hypertonic saline solutions for treatment of intracranial hypertension. Curr Opin Anaesthesiol. 2007;20(5):414-26.

46. Hirota K, Hara T, Hosoi S, Sasaki Y, Hara Y, Adachi T. Two cases of hyperkalemia after administration of hypertonic mannitol during craniotomy. J Anesth. 2005;19(1):75-7.

47. Malik ZA, Mir SA, Naqash IA, Sofi KP, Wani AA. A prospective, randomized, double blind study to compare the effects of equiosmolar solutions of $3 \%$ hypertonic saline and $20 \%$ mannitol on reduction of brain-bulk during elective craniotomy for supratentorial brain tumor resection. Anesth Essays Res. 2014;8(3):388-92.

48. Connolly Jr ES, Kader AA, Frazzini VI, Winfree CJ, Solomon RA. The safety of intraoperative lumbar subarachnoid drainage for acutely ruptured intracranial aneurysm: technical note. Surg Neurol. 1997;48(4):338-42.

49. Bien AG, Bowdino B, Moore $G$, Leibrock L. Utilization of preoperative cerebrospinal fluid drain in skull base surgery. Skull Base. 2007;17(2):133-9.

50. Mehta GU, Oldfield EH. Prevention of intraoperative cerebrospinal fluid leaks by lumbar cerebrospinal fluid drainage during surgery for pituitary macroadenomas. J Neurosurg. 2012:116(6):1299-303.

51. Sugrue PA, Hsieh PC, Getch CC, Batjer HH. Acute symptomatic cerebellar tonsillar herniation following intraoperative lumbar drainage. J Neurosurg. 2009;1 10(4):800-3.

52. Zhao J, Li G, Zhang Y, Zhu X, Hou K. Sinking skin flap syndrome and paradoxical herniation secondary to lumbar drainage. Clin Neurol Neurosurg. 2015;133:6-10.

53. Javouhey E, Richard N, Stamm D, Floret D. Lumbar drainage as treatment of refractory intracranial hypertension in bacterial meningitis. Intensive Care Med. 2008;34(6):1166-7.

54. Remeš F, Tomáš $R$, Jindrák V, Vaniš $V$, Setlík M. Intraventricular and lumbar intrathecal administration of antibiotics in postneurosurgical patients with meningitis and/or ventriculitis in a serious clinical state. J Neurosurg. 2013; 119(6):1596-602.

55. Abulhasan YB, Al-Jehani H, Valiquette MA, McManus A, Dolan-Cake M, Ayoub $\mathrm{O}$, et al. Lumbar drainage for the treatment of severe bacterial meningitis. Neurocrit Care. 2013;19(2):199-205.
56. Glimåker M, Johansson B, Bell M, Ericsson M, Bläckberg J, Brink M, et al. Early lumbar puncture in adult bacterial meningitis-rationale for revised guidelines. Scand J Infect Dis. 2013;45(9):657-63.

57. Açikbaş SC, Akyüz M, Kazan S, Tuncer R. Complications of closed continuous lumbar drainage of cerebrospinal fluid. Acta Neurochir (Wien). 2002;144(5):475-80

58. Shapiro SA, Scully T. Closed continuous drainage of cerebrospinal fluid via a lumbar subarachnoid catheter for treatment or prevention of cranial/spinal cerebrospinal fluid fistula. Neurosurgery. 1992;30(2):241-5.

59. Kawahara I, Tsutsumi K, Matsunaga Y, Takahata H, Ono T, Toda K, et al. Early awareness of cerebrospinal fluid hypovolemia after craniotomy for microsurgical aneurysmal clipping. Acta Neurochir (Wien). 2013;155(8):1543-8.

60. Loya JJ, Mindea SA, Yu H, Venkatasubramanian C, Chang SD, Burns TC. Intracranial hypotension producing reversible coma: a systematic review, including three new cases. J Neurosurg. 2012;117(3):615-28.

61. Staykov D, Speck V, Volbers B, Wagner I, Saake M, Doerfler A, et al. Early recognition of lumbar overdrainage by lumboventricular pressure gradient. Neurosurgery. 2011;68(5):1187-9.

62. Aghaei Lasboo A, Hurley MC, Walker MT, Surdell D, Song JK, Rosenow JM, et al. Emergent image-guided treatment of a large CSF leak to reverse "in-extremis" signs of intracranial hypotension. AJNR Am J Neuroradiol. 2008;29(9):1627-9.

63. Komotar RJ, Mocco J, Ransom ER, Mack WJ, Zacharia BE, Wilson DA, et al, Herniation secondary to critical postcraniotomy cerebrospinal fluid hypovolemia. Neurosurgery. 2005;57(2):286-92.

64. Chen C, Zhang B, Yu S, Sun F, Ruan Q, Zhang W, et al. The incidence and risk factors of meningitis after major craniotomy in China: a retrospective cohort study. PLoS One. 2014;9(7):e101961.

65. Leverstein-van Hall MA, Hopmans TE, van der Sprenkel JW, Blok HE, van der Mark WA, Hanlo PW, et al. A bundle approach to reduce the incidence of external ventricular and lumbar drain-related infections. J Neurosurg. 2010; 112(2):345-53

66. Schade RP, Schinkel J, Visser LG, Van Dijk JM, Voormolen JH, Kuijper EJ. Bacterial meningitis caused by the use of ventricular or lumbar cerebrospinal fluid catheters. J Neurosurg. 2005;102(2):229-34.

67. Coplin WM, Avellino AM, Kim DK, Winn HR, Grady MS. Bacterial meningitis associated with lumbar drains: a retrospective cohort study. J Neurol Neurosurg Psychiatry. 1999;67(4):468-73.

68. Hetem DJ, Woerdeman PA, Bonten MJ, Ekkelenkamp MB. Relationship between bacterial colonization of external cerebrospinal fluid drains and secondary meningitis: a retrospective analysis of an 8-year period. $J$ Neurosurg. 2010;113(6):1309-13.

69. Scheithauer S, Bürgel U, Ryang YM, Haase G, Schiefer J, Koch S, et al. Prospective surveillance of drain associated meningitis/ventriculitis in a neurosurgery and neurological intensive care unit. J Neurol Neurosurg Psychiatry. 2009;80(12):1381-5.

70. Kasper EM. Drain associated meningitis and ventriculitis remains a pivotal problem in neurointensive care: to understand their causes we need better surveillance data. J Neurol Neurosurg Psychiatry. 2009:80(12):1302

71. Schade RP, Schinkel J, Roelandse FW, Geskus RB, Visser LG, van Dijk JM, et al. Lack of value of routine analysis of cerebrospinal fluid for prediction and diagnosis of external drainage-related bacterial meningitis. J Neurosurg. 2006;104(1):101-8

\section{Submit your next manuscript to BioMed Central and we will help you at every step:}

- We accept pre-submission inquiries

- Our selector tool helps you to find the most relevant journal

- We provide round the clock customer support

- Convenient online submission

- Thorough peer review

- Inclusion in PubMed and all major indexing services

- Maximum visibility for your research

Submit your manuscript at www.biomedcentral.com/submit 